\title{
Nierozstrzygalność - drugie imię
} dekonstrukcji?

ABSTRACT. Winiecka Elżbieta, Nierozstrzygalność - drugie imię dekonstrukcji? [Undecidability - the second name of deconstruction?]. "Przestrzenie Teorii” 2, Poznań 2003, Adam Mickiewicz University Press, pp. 119-138, ISBN 83-232-1333-X, ISSN 1644-6763.

The article focuses on the problem of undecidability - the main feature of literature according to Derrida. Numerous examples of undecidability shows that it is not deconstruction which has found this kind of reading. For structuralists undecidability was a feature of poetry. Derrida broadens this onto all literary texts. Cancelling oposition between 'inside' and 'outside' he liquidates all natural for work contests: historical, sociological etc., and reduces literary text to the endless re-interpretation. It makes literary sigificants insignificant for culture and human being.

Exploration of the margins of the literary texts thwarts hierarchy of importancy and opens the door for different kinds of abuses. This is why the author argues with Derrida's thesis and guards traditional role of the autor, reader and literature.

O nierozstrzygalności powiedzieć można chyba bez przesady, że znana jest od zawsze. Do kwestii nierozstrzygalnych, nie tylko na obszarze literatury, należą pytania metafizyczne, np. czym jest prawda, co to jest rzeczywistość. Wiadomo o tym co najmniej od czasów Comte'a, który świadomie zrezygnował $\mathrm{z}$ dociekania „istoty rzeczy” i „prawd absolutnych", a w ślad za tym - z zajmowania się pytaniami metafizycznymi ograniczając się do racjonalnych metod poznawczych. Kwestie te projektują bowiem nierozstrzygalność epistemologiczną nie wynikającą ze struktury tekstu, lecz z natury problemu.

Natomiast $\mathrm{w}$ rozważaniach o nierozstrzygalności $\mathrm{w}$ proponowanym przez Derridę znaczeniu chodzi o to, co nierozstrzygalne $z$ powodu struktury dzieła, nie zaś z powodu niedostatecznych kompetencji odbiorcy, założeń światopoglądowych ani też z przyczyny rozmaitych możliwości wyobrażeń na temat świata przedstawionego otwieranych przez miejsca niedookreślenia. Sposób wypełnienia tych ostatnich zależy od czytelnika i nie jest w żaden sposób presuponowany przez strukturę dzieła. Nierozstrzygalność, definiowana tak, jak chce Derrida, leży po stronie literatury, a nie czytelnika; jest istotą literackości, jej warunkiem sine qua non. Tak przynajmniej chciałby jej prawodawca. 
Tym sposobem nierozstrzygalność stała się kluczowym pojęciem dekonstrukcji, wskazującym na niemożność odnalezienia jednego referentu, do którego odsyła tekst, a co za tym idzie - jednego znaczenia wylaniającego się $\mathrm{z}$ utworu. Strategia nierozstrzygalności dopuszcza nie tyle wielość interpretacji, z których żadna nie jest wierna, kompletna i spójna, ile swoistą podwójność semantyczną, sprzeczność wyłaniającą się z dyskursu. Derrida podkreśla, że nierozstrzygalność jest zawsze określoną oscylacją między możliwościami. Samo pojęcie nierozstrzygalności Derrida odnosi co prawda do opisu „tekstu generalnego”, a nie do praktyki lekturowej. Przyznaje jednak, że pewnego typu teksty, np. Platona, Mallarmégo, wyraźnie ukazują w praktyce lekturowej funkcjonowanie tej nieodłącznej strukturalnej cechy tekstualności.

'Nierozstrzygalniki' [indecidables] są dla Derridy jednostkami pozoru,

fałszywymi właściwościami werbalnymi, nominalnymi lub semantycznymi, które nie dają się już pojąć w opozycji filozoficznej (binarnej), której stawiają opór, mimo że w niej tkwią, jaką dezorganizują, nigdy nie tworząc rozwiązania $w$ formie dialektyki spekulatywnej (farmakon nie jest ani lekarstwem ani trucizną, ani dobrem ani złem, ani wnętrzem ani zewnętrzem ani dopełnieniem wnętrza, ani akcydensem ani istotą itd, hy men nie jest ani chaosem ani rozróżnieniem, ani tożsamością ani różnicą, ani spełnieniem ani dziewictwem, ani zasłoną ani odsłonięciem, ani wnętrzem ani zewnętrzem itd. gram nie jest ani signifiant ani signifie, ani znakiem ani rzeczą, ani obecnością ani nieobecnością, ani pozycją ani negacją itd.; rozsunięcie nie jest ani przestrzenią ani czasem $)^{2}$.

W rozmowie z Christianem Descompes'em Derrida następująco tłumaczył ich rolę w systemie dekonstrukcji:

Być może słowa tego typu lepiej niż inne wyznaczają miejsca, w których dyskurs nie może już panować, osądzać, rozstrzygać: pomiędzy tym, co pozytywne, i tym, co negatywne, dobre i złe, prawdziwe i fałszywe. Stąd usiłowanie wykluczenia ich z języka i z miasta w celu odtworzenia nieosiągalnej homogeniczności dyskursu, tekstu, organizmu politycznego ${ }^{3}$.

Wzorcowym poniekąd modelem działania zasady nierozstrzygalności stal się dla Derridy Mallarmégo Pierrot, assasin de sa femme [Pierrot, zabójca swej żony].Utwór ten jest opisem pantomimy odgrywanej przez mima Paula Margueritte, który zdradzony przez żonę przywiązuje ją do

${ }_{1}$ W przekładzie M. P. Markowskiego: trzeciego terminu - por. tego $\dot{z}$, Efekt inskrypcji. Jacques Derrida i literatura, Bydgoszcz 1997.

2 J. Derrid a, Pozycje, przeł. A. Dziadek, Bytom 1997, s. 42-43.

${ }^{3}$ Derridiana, wyb. i oprac. B. Banasiak, Kraków 1994, s. 17-18. 
lóżka i łaskocze w pięty tak długo, aż niewierna Colombina umiera ze śmiechu. Jak pisze o tym utworze sam Mallarmé:

Scena nie jest ilustracją jakiegoś realnego działania, lecz idei, w występnym, lecz także świętym związku małżeńskim [...], między pragnieniem i jego spełnieniem, postępkiem i wspomnieniem: tu uprzedzając, tam wspominając, w przyszłości, przeszłości, pod fałszywym pozorem teraźniejszości. Tak działa Mim, którego gra ogranicza się do nieustannej aluzji, bez rozbijania tafli: ustanawia więc środek: czystą fikcję ${ }^{4}$.

Zakwestionowana zostaje tym samym Platońska koncepcja mimesis, w której oryginał poprzedza kopię, naśladowane istnieje przed naśladowanym, rzeczywistość poprzedza swą imitację. Pierrot nie naśladuje bowiem niczego, co istniało wcześniej, sam ,jest jednocześnie bierny i czynny, materią i formą, autorem, środkiem i tworzywem swej mimodramy"5. Źródłowość rzeczywistości staje pod znakiem zapytania, jest tak samo prawdopodobna jak to, że opisana scena od początku do konca jest zmyśleniem symulującym własną prawdziwość. Różnica nie polega więc, zdaniem Derridy, na uprzedniości faktu wobec jego naśladownictwa, lecz na różnicy między Mimem grającym i Mimem odgrywanym, a co za tym idzie: na różnicy między fikcją wytwarzającą pozór rzeczywistości i pozór naśladowania. Po raz kolejny pojawia się pozorność prawdziwości dzialań - nie będących w istocie ani wyłącznie aktem performatywnym ani naśladownictwem, ani prawdą ani fałszem, ani tekstem ani metatekstem opowiadającym o swoim powstaniu, są bowiem zarazem i jednym i drugim. Ta cecha, powtarzająca się $w$ wielu utworach, jest jednym z głównych wyróżników literackiej nierozstrzygalności. Bez niej nie ma twierdzi Derrida - literatury. Literatura to nazwa wszystkiego, co nie poddaje się prawu przedstawienia (prawdy, obecności, sensu) i opiera się na zasadzie: ani tak, ani tak, ale jednocześnie i tak, i tak.

Tę dwuznaczność Derrida opisuje za pomocą słowa hymen, które wyposażone $\mathrm{w}$ podwójne wykluczające się, a zarazem równie aktualne znaczenia - odzwierciedla paradoksalność utworu Mallarmégo. Zgodnie $\mathrm{z}$ nieco archaicznym znaczeniem tego słowa, hymen jest synonimem ślubu, małżeństwa i jako taki scala w sobie sensy znoszące różnice: to tożsamość dwojga, skonsumowane małżeństwo, zniesienie granicy między pożądaniem i jego spełnieniem. Jednakże drugie znaczenie tego słowa to także przeciwieństwo pierwszego: to oddzielenie, oczekiwanie oraz dziewiczość „nie zapisanej jeszcze kartki” przywolana przez Mallarmégo. Hymen to granica pomiędzy zjednoczeniem i oddzieleniem, dwuznaczna obecność przeciwnych znaczeń konstytuująca nierozstrzygalność. Nierozstrzygalność jest tutaj „faktycznym mechanizmem pantomimy jako

${ }^{4}$ Cyt. za: M. P. Markowski, Efekt inskrypcji. Jacques Derrida i literatura, s. 235.

5 J. Derrida, La dissemination, Paris 1993, cyt. za: M. P. Markowski, s. 244. 
formy sztuki, ponieważ na podstawie samego naśladowania, bez słów, widz nie potrafi powiedzieć, czy śniony, czy wspominany, czy teraźniejszy akt jest właśnie odgrywany"6. Derrida uznał hymen za odzwierciedlenie struktury Mimique, zawieszonego pomiędzy opozycyjnymi sensami, które nawzajem się podtrzymują. Wskazuje, że to reguły gramatyki produkujące nieusuwalną dwuznaczność uniemożliwiają czytelnikowi wybór między sprzecznymi znaczeniami jednego słowa.

Z kolei w paragrafie 14 pierwszej części Krytyki władzy sądzenia Kant - a za nim komentujący go Derrida - koncentruje się na parergonie - słowie oznaczającym ozdobę, dekorację, ramę. Parergon wprowadza odwrócenie pojęć. Okazuje się, że tak naprawdę dzieło sztuki nie składa się z obrazu i ramy, czyli z wnętrza i zewnętrza: oba stanowią jedność za sprawą władzy sądzenia poznającego umysłu. Parergon ma rozbudzić w umyśle krytyczną intencję mającą stać się „naszym przewodnikiem po architekturze napisanego dzieła" . Jak dowodzi Kant w Krytyce władzy sq̨dzenia, piękna kolumnada objawia harmonię budowli, którą otacza, przestaje zatem być czymś wobec niej zewnętrznym, ujawnia się ich integralna więź, jak dopowiedziałby Derrida.

Fundamentalnym dla dekonstrukcji terminem stało się jednak $u z u$ petnienie (suplement). Derrida analizuje sposoby użycia tego słowa w tekstach Rousseau i dochodzi do wniosku, że okazuje się ono zarówno czymś koniecznym, jak i zbędnym, szkodliwym i pomocnym. Wymyka się logice alternatywy albo... albo, tworząc własną logikę uniemożliwiającą jednoznaczny wybór spomiędzy biegunów opozycji.

Czytając teksty Rousseau, Derrida pokazuje, że pismo zarówno uzupełnia głos, jak i jest odwleczonym przedstawieniem egzystencji za pomocą słów. Można je rozumieć na dwa sposoby: jako dopełnienie mowy czymś, czego jej brakuje lub też jako dodanie do niej czegoś zbędnego, bez czego ta doskonale mogłaby się obejść. Na przekór Platońskiej tradycji rozumienia roli pisma właśnie w taki lekceważący sposób, Derrida dowodzi, że u samego Rousseau pismo stanowi konieczne dopełnienie mowy, któremu udaje się przekazać wewnętrzną prawdę podmiotu, niedostępną za pośrednictwem słowa mówionego.

Podobnie funkcjonuje platoński farmakon. Ani przez chwilę nie możemy zapomnieć o dwuznacznym jego działaniu. Sprzeczne znaczenia współgrają, nakładając się na siebie, nie dopuszczając do redukcji do jednego z prostych składników języka. Derrida objaśnia tę dwuznaczność na przykładzie Fajdrosa Platona, gdzie pismo jawi się jako farmakon na pamięć i mądrość. Z jednej strony jest lekarstwem mającym dobroczynne

6 M. Riffaterre, Syllepsis, „Critical Inquiry” 1980, vol. 6, nr 4, s. 629.

${ }^{7}$ C. Gaudin, Zamknięcie tradycji filozoficznej: Derrida, eksplorator marginesów, w: Derridiana, op. cit., 
działanie: „pismo sprzyja pamięci, pomagając jej od wewnątrz, dzięki jej własnemu ruchowi, poznać prawdę"8. To dobroczynne działanie okazuje się jednak pozorne, z drugiej strony bowiem - referuje Derrida sąd Tamuza z Platońskiego Fajdrosa - Platon wpisuje w farmakon pisma możliwość odwrócenia jego działania: pismo może potęgować zło - „pod pretekstem zastąpienia pamięci pismo sprzyja zapominaniu; zamiast powiększać wiedzę, zmniejsza ją"9. Tłumaczenie słowa farmakon przez jednoznaczne w swym leczniczym działaniu lekarstwo zrywa zatem łączność między wpisanymi weń sprzecznościami, a tym samym niszczy tekstualność. Farmakon - czyli, w ujęciu Platona, pismo - jest bowiem jednocześnie lekarstwem i trucizną. Mając działanie dobroczynne, zalicza się zarazem do rzeczy przykrych. Nie usuwa też choroby, a jedynie powoduje jej przemieszczenie. Moc pisma (farmakonu) jest dwuznaczna:

Ma cechy wspólne zarazem z czymś dobrym i złym, przyjemnym i nieprzyjemnym.

Lub raczej to w tworzącej ją mieszaninie dają o sobie znać te przeciwieństwa ${ }^{10}$.

Jak pokazuje Derrida, jedna z wartości musi być zewnętrzna wobec drugiej, stanowić matrycę wszelkiego możliwego przeciwieństwa. Natomiast dwuznaczny farmakon - i pismo - nie pozwala się jednak zrozumieć za ich pomocą nie ma swej istoty ani wartości: negatywnej lub pozytywnej. Stwarza jedynie pozory: wyleczenia, wiedzy, pamięci, prawdy.

\section{3.}

Nierozstrzygalniki spokrewnione są z nierozstrzygalnymi zdaniami Kurta Gödla, które ten definiuje jako wchodzące w skład systemu, wyprowadzalne $\mathrm{z}$ nich, lecz zarazem nie dające się w świetle tej teorii wyjaśnić jako prawdziwe bądź fałszywe. Teza Gödla służyła zakwestionowaniu całościowości naukowych teorii i logicznych systemów.

Jeszcze bliżej Derridzie do Freuda, który badał języki semickie i indoeuropejskie, śledząc w nich słowa mające wykluczające się wzajemnie znaczenia. Freud w swej pracy $O$ przeciwnym sensie prastów poszukiwał analogii pomiędzy starożytnymi językami i pracą snu, która posługuje się tymi samymi środkami sprzecznych znaczeń.

Derrida zwraca szczególną uwagę właśnie na te słowa, które stanowią zarzewia nierozstrzygalności, uniemożliwiają tradycyjną hierarchizację i wybór sensów z gamy możliwości. Nie kwestionuje możliwości

8 J. Derrida, Farmakon, w tegoż: Pismo filozofii, wyb. i przedm. B. Banasiak, Kraków 1993, s. 52.

9 Tamże, s. 49.

10 Tamże, s. 48. 
rozstrzygnięcia w ogóle, jedynie eksponuje i eksploruje marginesy w poszukiwaniu „punktów oporu” nie poddających się łatwo pracy krytyka. W ten sposób wytrąca $\mathrm{z}$ ręki narzędzia dociekliwym hermeneutom kontynuującym drogę Gadamera i Ricoeura i kwestionuje możliwość systematyzacji pytań zadawanych tekstowi. On sam jest zwolennikiem „mrocznej” hermeneutyki - spod znaku Nietzschego i Heideggera - nie zmierzającej do konkluzji interpretacyjnych poszukiwan, a jedynie otwierającej niekończący się proces czytania. Ponadto - dowartościowuje ciemne, spychane na boczny tor miejsca tekstu. W miejsce dominanty prowadzącej dłoń interpretatora-strukturalisty wprowadza drugorzędne, marginesowe nierozstrzygalniki, czyniąc je węzłowymi miejscami tekstu.

Pomaga mu w tym swoiście pojmowana idea pisma ogólnego rozumianego jako sama możliwość zapisu sensu zarówno w piśmie, jak i mowie. Ową ogólną możliwość odzwierciedla gram - umiejscowiony znacznie głębiej niż fonem i grafem - definiowany jako instancja decydująca o samej możliwości nadawania i odbierania sensu słów. Gram niweluje sprzeczność pomiędzy wewnętrznością mowy wywodzonej ze świadomości i zewnętrznością aktu pisania lączącego się z gestem stawiania znaków w przestrzeni. Odwracając technologiczną hierarchię uprzedniości mowy wobec pisma, Derrida tworzy gramatologię. Zarówno mowa, jak i pismo są już tylko znakami. Nie ma sensu opozycja pismo-głos, bo obie formy są już tylko dwiema modalnościami zapisu.

Autor $O$ gramatologii, schodząc na poziom pierwotny wobec opozycji mowa-pismo, szuka w słowach, tj. dźwiękach splecionych z grafią, śladu pierwotnego pisma i bawi się „gramami”. Wnika do wnętrza słów, poszukuje ich semantycznego bogactwa. Nie gra słowami, lecz literami. Z gry gramów wyłania się Derridiańska różnia. Gra liter w semantycznie niespokrewnionych ze sobą słowach może rozbić lub unicestwić jeden sens, by w jego miejscu zasugerować możliwość innych sensów. Ta praktyka „pisma uogólnionego" rozbija unieruchomione pojęcia, zmusza do myślenia o pierwotności znaku, o traktowaniu go w kategorii śladu, który nie ma bezpośredniego związku z myślą.

Lecz przecież wykorzystanie semantycznego potencjału słów jest podstawowym budulcem poezji opartej na grach złożoną biografią słowa i związków międzysłownych.

„Wieloznaczność [ambiguity] jest wewnętrzną, nieodłączną cechą [...] poezji" - stwierdził ponad czterdzieści lat temu Roman Jakobson ${ }^{11}$, wyjaśniając, że „Dominowanie funkcji poetyckiej nad funkcją poznawczą nie usuwa oznaczenia czyni je tylko wieloznacznym. Dwu-znaczny komunikat znajduje odpowiednik $\mathrm{w}$ rozdwojonym nadawcy, $\mathrm{w}$ rozdwojo-

11 R. Jakobson, Poetyka $w$ świetle językoznawstwa, w: Wspólczesna teoria badań literackich za granicq, red. H. Markiewicz, Kraków 1974, s. 56. 
nym odbiorcy, a prócz tego w rozdwojonym oznaczaniu”. Jako przykład podaje wyjęte z bajek ludowych stwierdzenie: „to było i nie było"12, mogące zresztą posłużyć jako zastanawiająco trafna definicja stanu zawieszenia w referencjalnej próżni utworów takich jak Mimique Mallarmégo.

Wkrótce po Jakobsonie kwestię wieloznaczności komunikatów poetyckich podjął Janusz Sławiński, nazywając stan słów w tychże „dziwieniem się" swoim sąsiedztwem. Ta dynamiczna zależność - tłumaczy polski strukturalista - ,jest relacją semantyczną, polega na uwielokrotnieniu sensów i na zawieszeniu wyboru pomiędzy nimi, na jednoczesnej akceptacji wszystkich napomkniętych możliwości znaczeniowych słów, które spotkały się w sekwencji”13.

Czytając te sformułowania, odnieść można wrażenie, że obcujemy $\mathrm{z}$ jednym $\mathrm{z}$ manifestów dekonstrukcji Jacques'a Derridy, którego działanie interpretacyjne polega na „zaszczepianiu” pojęć na sobie i konfrontowaniu ich ze sobą, na wydobywaniu sprzeczności z jednoznacznych na pozór słów i pokazywaniu gwałtownych zwrotów mowy, która sama kwestionuje to, co chce powiedzieć. I zaiste, nie ma w tej zbieżności nic dziwnego, Derrida burzy bowiem gmach strukturalizmu (określa to jako „gest zarazem strukturalistyczny i antystrukturalistyczny"14), by z jego fragmentów zbudować własny przyczółek. Tak też dzieje się w przypadku nierozstrzygalności, która jest „przemieszczonym i odwróconym” echem wieloznaczności produkowanej przez mowę poetycką. Derrida utożsamia literackość z nierozstrzygalnością, zgodnie z którą niemożliwe jest dokonanie wyboru między jedną z możliwości. Schodząc poniżej poziomu leksykalnego pokazuje, że żadne słowo nie jest ani jednoznaczne, ani przezroczyste. Całość założona ponad słowem rozsypuje się poniżej niego. Innymi słowy: istotą literackości jest, parafrazując definicję poezji Janusza Sławińskiego, nieustanna rein ter pretacja znaków językowych ${ }^{15}$.

Prawdziwą kopalnią przykładów na nierozstrzygalność semantyczną tekstu może być poezja lingwistyczna, przede wszystkim Mirona Białoszewskiego i Tymoteusza Karpowicza. O nierozstrzygalności niemożliwych światów w tomie Odwrócone światto pisał w Tekstowym świecie Ryszard Nycz, tu zatem skoncentruję się przez chwilę na Białoszewskim.

Niektóre jego utwory tworzą z pewnością aporetyczny efekt nierozstrzygalności. Jej przyczyną jest przede wszystkim dekontekstualizacja idealna sytuacja lekturowa dekonstrukcjonistów - zaś zadanie czytelnicze polega na tym, by odnaleźć repertuar możliwych uzasadnień dla

12 Tamże, s. 57.

13 J. Sła wiński, Wokót teorii języka poetyckiego, w: Dzieto, język, tradycja, Warszawa 1974 , s. 111 .

14 Rozmowa Christiana Descompes'a z Jacque'em Derridą, w: Derridiana, s. 14.

15 Por. J. Sła wiński, Wokót teorii języka poetyckiego, s. 112. 
konkretnego tekstu. Szczególnie bliskie pisaniu Białoszewskiego wydaje się być zakwestionowanie przez rozsunięcie, nadwyżkę składni nad semantyką czyli logikę hymenu, jedności tematu gwarantowanej jednością słowa. Lektura jego utworów domaga się aktywizacji powinowactw formalnych, fonicznych lub graficznych, ech, nawiązań nie tylko w strukturze danego tekstu, ale i w sferze intertekstualnej.

Nierozstrzygalność rozgrywa się tu na poziomie granicznym między wewnątrztekstową niezrozumiałością operacji dokonywanych na systemie języka a zewnątrztekstową nieokreślonością sytuacji ,ja” lirycznego. Instancją spajającą byłaby osoba poety balansująca na granicy tych dwóch - sprzecznych ontycznie - światów. Byłaby, gdyby nie fakt, że intencja autora jest dla dekonstrukcjonistów już tylko jednym z poziomów interpretacyjnych dzieła, nie zaś nadrzędną instancją rządzącą semantyką tekstu. Tak więc czytelnik, umieszczony wśród pleniących się znaczeń, prowadzi niekończącą się tekstualną grę $\mathrm{z}$ utworem, o której powiedzieć można tylko jedno: że nigdy się nie kończy. To było i nie było?...

W przypadku nierozstrzygalności semantycznej mówić możemy o obecności w punkcie wyjścia takich tropów, jak homonimia, homofonia, polisemia, antynomiczność i wszystkie paradoksalne zjawiska coincidentia oppositorum: zbiegi przeciwstawień, do których zalicza się choćby oksymoron, bazujące na semantyce słów, ingerujące $w$ ich znaczenia. O ile jednak polisemia zakłada możliwość wykładni całego sensu, to rozsiewanie, znamionujące według Derridy każdy tekst literacki, neguje możliwość totalizacji znaczeń i odsłonięcia „całej prawdy” tekstu. Nierozstrzygalność nie opiera się według niego na semantycznym bogactwie słowa, lecz na grze składni, uniemożliwiającej jednoznaczną wykładnię. Dlatego nierozstrzygalność semantyczna nie dotyczy nigdy znaczeń poszczególnych słów, lecz całych konstrukcji składniowych, uruchamiających proces rozsiewania znaczen.

Polisemia otwierała pole możliwości interpretacyjnych, hermeneutycznych prób zrozumienia utworu. Rozsiewanie jest zjawiskiem z obszaru struktury dzieła, składniowym trickiem ujawniającym swą nadwyżkę semantyczną w odniesieniu do spodziewanych znaczeń. Poetykę dysseminacji tłumaczy Derrida w Psyché. Odkrywanie innego jako interferencję rozbieżnych i różnopoziomowych wskaźników integracji:

Niezgodność składni przedstawienia ze schematami logicznej interpretacji uruchamia mechanizm reprezentacji, który wytwarza tyleż uporczywe, co bezowocne (bo podważające się wzajemnie, odwracalne) antynomiczne przedstawienia ${ }^{16}$.

16 J. Derrida, Psyché. Odkrywanie innego, przeł. M. P. Markowski, w: Postmodernizm. Antologia przektadów, wybór, oprac. i przedm. R. Nycz, Kraków 1998, s. 114. 
Derrida odróżnia więc nierozstrzygalność od polisemii. Twierdzi, że -

horyzont semantyczny, który rządzi zazwyczaj pojęciem komunikacji, zostaje przekroczony czy też rozerwany przez wkroczenie pisma, czyli pewnego rozplenienia, które nie sprowadza się do polisemii. Pismo się czyta, nie daje ono okazji - „w ostatniej instancji” - dla hermeneutycznego rozszyfrowania, dekryptażu sensu bądź prawdy ${ }^{17}$.

Zwalczając wszelkie przejawy myślenia wartościami, mogącego prowadzić do zawłaszczenia sensu, Derrida toczy bój z zachodnią metafizyką, tłumacząc, że -

opozycja metafizycznych pojęć (na przykład mowa/pismo, obecnośćnicobecność itd.) nigdy nie jest jakimś vis-à-vis dwóch terminów, lecz pewną hierarchią i układem pewnego podporządkowania. [To dlategol Dekonstrukcja nie może się ograniczyć czy też przejść bezpośrednio do jakiejś neutralizacji: musi - podwójnym gestem, podwójną nauką, podwójnym pismem - dokonywać obalenia klasycznej opozycji $i$ ogólnego przemieszczenia systemu. [...] Dekonstrukcja nie polega na przechodzeniu od jednego pojęcia do innego, lecz na obalaniu i przemieszczaniu pewnego porządku pojęciowego, a także porządku niepojęciowego, z którym tamten się lączy ${ }^{18}$.

Największą zaletą dekonstrukcji wydaje się to, że stara się ocalić te wartości utworu, które w perspektywie strukturalistycznej ginęły gdzieś $\mathrm{w}$ trakcie interpretacji. Umieszczanie dzieła w tradycji literackiej, a zatem porównywanie nieznanego do już znanego, zawsze przynosi ryzyko, że niedostatecznie wyrobiony czytelnik przeoczy $w$ utworze to, co nie respektuje konwencji (a co najbardziej nośne znaczeniowo), a zatem to, co najbardziej wartościowe w dziele.

Derrida poradził sobie $\mathrm{z}$ tym problemem, rezygnując $\mathrm{z}$ tradycji literackiej. Czytelnik, zwolniony z konieczności przywoływania swoistego dla dzieła kontekstu, może pozwolić sobie teraz na pełną dowolność. Przywołując wszystkie - także te najbardziej odległe i sprzeczne $z$ intencją autora znaczenia słów - kroczy zawiłymi ścieżkami wyznaczanymi przez interpretacyjne gry, nie dbając o dochowanie wierności czemuś, co wszak nie istnieje jako samoistny, raz na zawsze określony i zdefiniowany przedmiot. Nie ma już zatem czego ryzykować.

4.

Nierozstrzygalność etyczną odnajdujemy już w tragedii greckiej. Konflikt moralny między bohaterem i siłą wyższą stawiał go nieuchronnie w obliczu aporii. Nieuchronność klęski powodowanej przez rozstrzy-

17 J. Derrid a, Sygnatura, zdarzenie, kontekst, w: Pismo filozofii, s. 281.

18 Tamże, s. 281. 
gnięcie dylematu na korzyść którejkolwiek z racji sprawia, że idealnym rozwiązaniem byłoby zastygnięcie w stanie dynamicznej równowagi pomiędzy nimi. Zarazem jednak niemożność pogodzenia sprzecznych stanowisk czyni nierozstrzygalność momentem przejściowym, nie dającym się utrzymać. Powiedzieć bez przesady można, że stanowi ona kwintesencję kategorii tragizmu jako starcia równorzędnych racji moralnych.

Prawdziwą kopalnią przykładów na nierozstrzygalność ontologiczną stały się utwory romantyczne - z IV częścią Dziadów Mickiewicza na czele. Zwięzłą definicję nierozstrzygalnego statusu ontologicznego romantycznego bohatera podaje mistrz poetyckiej nierozstrzygalności, Miron Białoszewski:

trup nie trup

kryminal nie kryminal

Dalsza charakterystyka Gustawa-Pustelnika z IV części Dziadów czyni jednak tę nierozstrzygalność nie tak już oczywistą:

Jest zakochany. Niecierpliwy. Histeryk. Przebija się. I żyje. Zabija. I dalej gada. Jako trup? Niby sam to mówi. Ale on mówi i o niej, że umarła. A ona żyje. I on żyje. On tak naprawdę to nie chce przestać żyć. Dlatego nie trup. I nie kryminał. Jej też nie poćwiartuje. Wystarczy pomyśleć, wyobrazić sobie coś, i to już satysfakcja. Po co to zaraz dosłownie spełniać? ${ }^{19}$

Białoszewski rozstrzyga wątpliwości, tłumacząc nieoczywistość bytu Gustawa w sposób psychologiczny i... unicestwia kwestię. Jednakże nierozstrzygalność romantycznych zjaw jest cechą, która nie chce się tłumaczyć $w$ żaden $z$ logicznych systemowych sposobów: jest specyfiką romantycznego światopoglądu i systemu wartości.

Także poetyckie światy Bolesława Leśmiana zapełniają istoty ni to ze świata żywych, ni umarłych, wiodące żywot po obu stronach granicy i kwestionujące dychotomiczny podział na żywych i umarłych. Prawdziwą karierę nierozstrzygalności przyniósł wszak modernizm. Moda na niewyrażalność, nieprzedstawialność i niedefiniowalność nastała wraz z symbolizmem. W odniesieniu do takich dzieł Tzvetan Todorov użył po raz pierwszy określenia 'nierozstrzygalne', mając na myśli poezję Rimbauda. W tym przypadku nierozstrzygalność bliska jest pojęciu wieloznaczności cechującej symbol.

Derrida nie twierdzi zresztą, że jest odkrywczy w tym, co głosi. Chodzi mu przede wszystkim o walkę $\mathrm{z}$ totalizującą siłą Teorii poprzez obnażenie w tekście miejsc nie poddających się wyjaśnieniu. Derrida wytrwale śledzi i wydobywa na powierzchnię miejsca dekonstruujące całościowy sens. Koncentrując się na słowach oscylujących między sprzecz-

${ }^{19}$ M. Białos zewski, O tym Mickiewiczu jak go mówię, „Odra” 1967, nr 6. 
nościami, dowartościowuje marginesy, bada to, co w tradycyjnej interpretacji spychane było na plan dalszy lub pomijane. Swiadomie niweczy w ten sposób hierarchię tekstowych znaczeń, obsesyjnie bojąc się totalizującej władzy wszelkich uporządkowań. Taka praktyka pozwala, jego zdaniem, po pierwsze na uwolnienie utworu spod władzy dyskursu teoretycznoliterackiego i przemówienie własnym głosem (co zresztą stanowi cel utopijny, bowiem każda lektura jest już podporządkowaniem utworu jednostkowemu odczytaniu, choćby było ono najbardziej otwarte na inność tekstu), po drugie zaś - otwiera literaturę na wielość odczytań, czyniąc ją miejscem twórczego myślenia i początkiem łańcucha kolejnych głosów stanowiących równorzędne utwory. Derridzie chodzi o to, by „Nieskończonym rachunkiem nierozstrzygalnika udaremnić hermeneutyczny podbój"20. Czy jednak nierozstrzygalność to rzeczywiście cecha tekstu czy może raczej poznającego intelektu (i metodologii)? Innymi słowy, czy problem leży po stronie literatury, czy też po stronie czytelnika, który własne poglądy transponuje na dzieło?

Dekonstrukcja jest metodą świadomie nastawioną na odkrywanie w tekście miejsc stawiających opór całościowej interpretacji. Otwiera i przemieszcza wszelkie porządki znaczeń, wychodząc $\mathrm{z}$ założenia, że teksty zawsze zawierają miejsca aporetyczne, wymykające się logice interpretacji. Nierozstrzygalniki to właśnie aporetyczne momenty w tekstach, ujawniane w trakcie lektury.

W dziele wiele znaczeń wymyka się autorskiej intencji, która stanowi tylko jeden z poziomów tekstualnej gry i nie prowadzi do ostatecznego rozstrzygnięcia jego sensu. W rozważaniach o sprzecznościach zawierających się w slowie farmakon Derrida stwierdza:

Platon może niekiedy przyjmować te rodzaje komunikowania, korytarze sensu, oświetlać je, [...] Podobnie w innych przypadkach Platon może nie widzieć związków, zostawiać je w cieniu lub zrywać. Związki te zachodzą jednak same przez sięं21.

W komentarzu do tej kwestii Ryszard Nycz przywołał właśnie kategorię nierozstrzygalności, jako najtrafniej odzwierciedlającą stan semantycznego niedomknięcia:

Wyprowadzone na powierzchnię sprzeczne porządki znaczeń wytwarzają nieodmiennie efekt niekonkluzywności, nierozstrzygnięcia i dyspersji sensu, pozbawionego kontekstowych granic $[\ldots]^{22}$.

Tak więc dekonstrukcja celowo czyta utwór w taki sposób, by dać mu szansę nieustającego otwierania wszelkich komentarzy do siebie na ko-

${ }^{20} \mathrm{~J}$. Derrida, Ostrogi, s. 56.

${ }^{21}$ J. Derrida, Farmakon, w: Pismo filozofii, s. 49.

22 R. Nycz, Tekstowy świat, s. 40. 
lejne uzupełnienia. Nie może być jednoznacznego rozstrzygnięcia o sensie danego tekstu. Opozycja błędność/poprawność jest $w$ dekonstrukcji nieprzydatna, a proces lektury nigdy się nie kończy. Do łańcucha interpretacji można dopisać zawsze kolejne ogniwo. Opór tekstu ma zawsze dynamizować interpretacyjną grę.

$\mathrm{O}$ ile w idei powrotu do tekstu i wnikliwego, bezinteresownego czytania kryje się przesłanie bliskie tradycyjnej filologii, to jednak sam pomysł rezygnowania $z$ dociekania prawdy tekstu na rzecz jego twórczej lektury brzmi groźnie dla badaczy literatury, a w konsekwencji dla niej samej. Okazuje się bowiem, że Derrida najchętniej wygnałby ich z państwa jako przedstawicieli zawłaszczającej i groźnej ideologii ${ }^{23}$. Co gorsza jednak, rezygnacja $z$ systematyzacji prowadzi do anarchii w świecie literatury. Skoro nie ma już ideału prawdy i właściwego sensu utworu, to utwór kompozycyjnie niedoskonały, nie stanowiący harmonijnej jedności, okazałby się jeśli nie bardziej wartościowy (Derrida jest wrogiem hierarchizacji), to co najmniej bardziej podatny na twórcze dopełnienia i czytelnicze głosy. A zatem - bliższy Derridiańskiemu ideałowi.

Czy warto płacić tak wysoką cenę za dojście do racji znanej i wykładanej na uniwersytetach od zawsze?

\section{5.}

Nierozstrzygalność $\mathrm{w}$ rozumieniu tradycyjnym pojawia się $\mathrm{w}$ Waiserze Dawidku Pawła Huelle - utworze, w którym w miejsce sacrum pojawia się tajemnica ewokująca nierozstrzygalność. Jest ona wpisana $w$ fabułę, nie zaś w strukturę dzieła.

Przypomnijmy, że bohater-narrator, prowadzący po latach prywatne śledztwo w sprawie tajemniczego zniknięcia Weisera, sam sceptycznie podchodzi do możliwości jego powodzenia:

Nie wiem, czy w ogóle jest jakaś odpowiedź. To właśnie z jej braku zapełniam linijki papieru, niczego nie będąc pewnym ${ }^{24}$.

Odwiedzany po latach przez narratora kolega Szymek potwierdza jego wątpliwości co do rzeczywistego przebiegu wypadków sprzed lat: „mogło być tak, ale mogło też być inaczej”25.

${ }^{23}$ Postuluje zatem, by, „naruszając normy i konwenanse pisania uniwersyteckiego”, „pisać inaczej, zachowując jednocześnie filozoficzną umiejętność czytania i kompetencję, czego [...] ani zwolennicy tak zwanej analizy wewnętrznej, ani pozytywiści humanistyki nie czynią - nawet jeśli sprawiają odmienne wrażenie" [Rozmowa Christiana Descampes'a $z$ Jacques'em Derrida, s. 16].

${ }^{24}$ P. Huelle, Weiser Dawidek, Londyn 1992, s. 14. Kolejne cytaty wg tego wydania.

25 Tamże, s. 100. 
Nierozstrzygalność jawi się tu jako cecha umysłu podmiotu poznającego. Gdy bohater przyznaje po latach: „Dzisiaj niczego nie jestem pewien"26 to chodzi tu raczej o niepewność czy niejednoznaczność, ewokującą tajemnicę, która może zostać wyjaśniona lub nie, pozostawia jednak otwartą alternatywę: wybór pomiędzy tak lub nie.

Weisera nie bawiły układy proste i nieskomplikowane, za każdym razem dążył do coraz subtelniejszych efektów. Teraz jest to dla mnie najzupełniej oczywiste. Następnym razem, kiedy ziemia zadrżała od eksplozji, ujrzeliśmy obraz, który przewyższył najśmielsze oczekiwania. Jeśli powiem, że był to francuski sztandar, nie skłamię, ale nie powiem też prawdy. Jeśli napiszę, że przypominało to trzy wirujące obok siebie słupy, każdy innego koloru, to też nie będzie to ścisłe nie odda w pełni istoty rzeczy.

Czy zresztą w ogóle można oddać istotę rzeczy? Obawiam się, że nie, i właśnie dlatego nie piszę książki, o której myślę, że dawno już powinna być napisana ${ }^{27}$.

Według Briana McHale przejście od powieści modernistycznej do postmodernistycznej dokonało się za sprawą zmiany dominanty $\mathrm{z}$ epistemologicznej na ontologiczną ${ }^{28}$. Tę pierwszą cechuje obecność problematyki epistemologicznej i pytań o istotę poznawanego świata i poznający podmiot, jego możliwości i ograniczenia, a wreszcie granice poznania i samej „niepoznawalności”.

W powieści postmodernistycznej kwestie te podporządkowane zostają problemom związanym ze sposobem istnienia świata projektowanego przez tekst literacki, konfrontacji miedzy różnymi światami i przekraczania granic między nimi, a także sposobowi istnienia samego tekstu oraz świata(ów) przezeń projektowanego(ych).

Weiser Dawidek byłby więc według kategoryzacji McHale’a przykładem powieści egzemplifikującej klasyczny poznawczy dylemat modernizmu.

I tu właśnie przebiega granica pomiędzy „klasycznym” i Derridiańskim ujęciem nierozstrzygalności. O ile bowiem dotychczas nierozstrzygalność była problemem natury poznawczej, teraz przemieściła się na obszar ontologii. Jak wiadomo, Derrida zajmuje stanowisko antymetafizyczne, a zatem nierozstrzygalność wskazywana przez niego również abstrahuje od kwestii metafizycznych.

Literatura może też balansować pomiędzy wyjaśnieniami epistemologicznymi i ontologicznymi, nie znajdując dla nich ostatecznego rozstrzygnięcia. Tak dzieje się w niewielkiej książce Nataszy Goerke Księga

26 Tamze, s. 54.

${ }_{27}$ Tamże, s. $79-80$.

28 Por. B. McHale, Od powieści modernistycznej do postmodernistycznej: zmiana dominanty, przeł. M. P. Markowski, w: Postmodernizm. Antologia przekladów, wybór, oprac. i przedm. R. Nycz, Kraków 1998. 
Pasztetów. Ten zbiór absurdalnych opowiadań, będący przewrotną trawestacją Księgi Przystów, zmusza czytelnika do stawiania pytań o sens sfragmentaryzowanych narracji oraz o płaszczyznę, do której można byłoby odnieść ich zdestablizowane quasi-rzeczywistości. Nie daje natomiast żadnych odpowiedzi. Doprowadzone ad absurdum kwestie bytu, tożsamości $\mathrm{i}$ istnienia jednostkowej świadomości każą odczytywać te groteskowe opowiadanka jako egzemplifikację ontologicznej nierozstrzygalności kreowanego świata oraz aspiracji literatury do metafizycznego usensawiania zdarzeń. Wykładnikiem tych pytań staje się - w odróżnieniu od Weisera Dawidka - konstrukcja tekstu: rozbicie spójności narracji, brak wykładników diegesis, nieustanna zmiana perspektyw narracyjnych, niemożliwe do określenia czas i przestrzeń, otwierająca się przed czytelnikiem raczej jako otchłań bez dna aniżeli możliwa do określenia sceneria. Ot, choćby opowiadanie Sosoma Granda to etiuda wątpliwości na temat sposobu bycia, czy, mówiąc obrazowo, stanu skupienia tytułowej Sosomy. Początek, przez eliminację kolejnych możliwości, obiecuje dotarcie do odpowiedzi na pytanie o jej tożsamość:

Sosoma Granda, aczkolwiek imię jej pochopnie kojarzono z nazwą indiańskiego miasteczka, nie była miasteczkiem; nie była też ani rzeką, ani malowniczą przełęczą, ani głębinową rybą czy też książką o Indianach Bella Bella; co więcej: nie była nawet zupą z ryjków mięczaków, przyrządzaną przez Kwakiutlów na przekór Indianom Bella Bella.

Kim zatem była?

Gustujący w kobietach dwupalcy demon Kawaka na widok Sosomy uciekł, wyrzekłszy słowa, które z czasem uznano za wieszcze: Ta, której nie zjem, jest tą, której nie ma.

Tą, której nie zjadł, była właśnie Sosoma Granda.

- Kogo zatem nie zjadł Kawaka? Zastanawiała się, żując własny ryjek, Sosoma, aż zredukowawszy rozważania do jednego do jednego tylko pytania, zawołała: Skoro mnie nie ma, to kim jest ta, która pyta?

Było to pytanie o tożsamość pytającego: bardzo niebezpieczna igraszka z umysłem, pociągająca tych zwłaszcza, których tożsamość jest potężnym, acz doszczętnie strzaskanym lustrem ${ }^{29}$.

Jak było do przewidzenia, odpowiedź na pytanie nie pada. Krótka historia Sosomy znów, jak Weiser Dawidek, kończy się poznawczą klęską spuentowaną przez narratora:

I to już koniec historii: wszak życie to nie spacer w czapce niewidce, ani książka o Indianach Bella Bella, ani wesołe miasteczko; co więcej: to nawet nie piknik urządzony przez Kwakiutlów pod palmą czy zupa z ryjków mięczaków.

Życie jest schabowym kotletem, który trzeba jeść, trawić i nie kombinowaćc ${ }^{30}$.

${ }^{29}$ N. Goerke, Księga Pasztetów, Poznań 1997, s. 73.

30 Tamże, s. 74. 
Lecz $\mathrm{w}$ przeciwieństwie do utworu Pawła Huelle, tutaj nierozstrzygalność przenosi się na poziom ontologii. $\mathrm{O}$ zmianie dominanty dokonującej się w prozie Nataszy Goerke można powtórzyć za Brianem McHale:

Niemożliwa do uchwycenia epistemologiczna niepewność staje się w pewnym punkcie ontologiczną wielością lub niestabilnością: doprowadź pytania epistemologiczne wystarczająco daleko, a zaczną się one „przechylać” na stronę onto$\operatorname{logii}{ }^{31}$.

Teksty zebrane w Księdze Pasztetów określić można jako aporetyczne. Aporia to $\mathrm{z}$ greckiego bezdroże, bezradność, (od aporos - nieprzebyty, trudny). Innymi słowy: ścieżka nie do przejścia. Znaczenia są tu, jak określa Terry Eagleton, „rodzajem ciągłego migotania obecności i nieobecności jednocześnie. Czytanie tekstu przypomina bardziej śledzenie tego procesu ciągłego migotania, niż liczenie paciorków naszyjnika".

To migotanie rozgrywa się między znakiem i jego zawartością, między dosłownością i figuratywnością, między przedstawieniem a nieprzedstawieniem. Bohaterowie opowiadań Goerke uciekają więc „przed rzeczą, chroniąc się w jej nazwie”, stają się „zarówno ptakiem, jak ornitologiem" zgodnie z cytowaną w motcie jednego z opowiadań definicją Susan Sontag ${ }^{32}$.

Prozy te opowiadają zarówno o rzeczywistości tekstowej, jak i jej kreacji, przenosząc jednak tę kwestię z poziomu świadomości narratora na poziom samej poetyki dzieła. Opowiadanie pod dwuznacznym tytułem Fatamorgana kończy się np. monologową kwestią narratora-wielbłąda wyścigowego (przez analogię do konia wyścigowego):

Będąc garbem na swym własnym grzbiecie, przekraczam kolejną metę i obserwując jak spoceni mężczyźni skrapiają wodą moją martwą twarz, pędzę dalej [s. 48].

Opowiadania pełne są bohaterów mających kłopoty z własnym istnieniem: "Czy umarła na niby, czy naprawdę" nie ma pewności bohater Kanonu, Samuel Beckett ze snu bohaterki Drugiej miłości „udawał, że udaje", a dla redaktora Malera Domskiego z $3 D$ jawa jest tak nieznośna, że chroni się przed nią w przytulnej sali kina lub ucieka myślami w przeszłość. Augustyn Hrab z Dla pożytku sztuki jest zjawą z pogranicza snu i rzeczywistości, o którego istnieniu otrzymujemy wyłącznie sprzeczne informacje: że ów mężczyzna jest tylko snem bohaterki, że jego „niemal boska wszechobecność” w życiu pisarki Helen Hammill wpłynęła na jej życie, choć ten nigdy nie zwrócił na nią uwagi:

${ }^{31}$ B. Mc Hale, op. cit., s. $350-351$.

32 N. Goerke, Fatamorgana. 
Istniejący realnie Hrab niewiele zdaje się mieć wspólnego z Hrabem postrzeganym przez Hammill [s. 20].

Do tej pory kwestie te noszą cechy natury poznawczej: dotykają problemów względności i subiektywizmu poznania, punktów widzenia oraz granic poznawczych. Finał opowiadania dokonuje jednak gwałtownego zwrotu perspektywy. Oto bowiem „Zaproszony na pogrzeb Augustyn Hrab na oczach zebranych przemienił się w brzozę i wyznał: 'Zwodziłem ją dla pożytku Sztuki" (s. 21). To już wyraźna wolta od kwestii epistemologicznych ku ontologicznej sprzeczności możliwych światów istniejących obok siebie nie na zasadzie wykluczenia, lecz łączności.

Kwestia wielości światów wyartykułowana zostaje jeszcze dobitniej w zamykającym tomik opowiadaniu Wymiar Zero:

Milena wtuliła buzię w poduszkę.

Mam zniknąć?, spytał Mieszko. Nie, zostań, westchnęła. Tylko dlaczego to wszystko takie trudne, chcę powiedzieć A, mówię B, a oba tak samo prawdziwe jak upływ czasu. Czy stworzono nas w tym samym języku?

Dry shit on the stick! zawołał wtedy Mieszko i Milena pomyślała: A jednak. On to czyta. Któż zatem pisze scenariusz? Bo jeśli Boga nie ma, i jeśli to nie my, to $\mathrm{kim} / \mathrm{czym}$ jest siła zdolna do kreacji tak monstrualnych powikłań?

Lniany Mieszko przytulił Milenę i zniknął [s. 97].

"On to czyta" oznacza w tym kontekście tyle, że monolog bohaterki jest dostępny jej tekstowemu partnerowi w formie zapisu, takiej samej, z jaką mamy do czynienia my, czytelnicy. Tym samym Mieszko umiejscawiałby się zarówno na poziomie wykreowanego świata opowieści, jak i na płaszczyźnie odbioru dzieła, przynależnej czytelnikowi. Tajemniczy Mieszko byłby zatem instancją wszechobecną, zarówno zewnątrz-, jak i wewnątrzliteracką, byłby bohaterem i czytelnikiem w sposób, jaki przynależał dotychczas tylko świadomości narratora pierwszoosobowego.

Odpowiedź na wątpliwości bohaterki jest tylko na pozór prosta. Siłą zdolną do kreacji jest, czy raczej: mógłby być, oczywiście autor. Pozwalając sobie na absolutną wolność tworzenia, wolność tę jednak zmienia w anarchię, gdy burzy oczekiwania czytelnika i odbiera mu wszelkie dostępne sposoby oswojenia tekstu, unieważniając granicę wnętrze-zewnętrze. Najbardziej prawdopodobną odpowiedzią na pytanie o sens tych opowiastek jest więc wskazanie na brak logicznych podstaw umożliwiających rozpoznanie ich sensu. Innymi słowy: bezsens jest jedynym pozytywnym znaczeniem niesionym przez te opowiadania i jako literacka konstrukcja jest tekstowym wyznacznikiem nierozstrzygalności. Poetyka opowiadań Nataszy Goerke jest wykładem na temat samej tekstowości. Odtwarzając mimesis procesu powstawania tekstu literackiego, w żaden 
sposób nie odnoszą się do rzeczywistości pozatekstowej. Są samonapędzającą się machiną.

W tej sytuacji można uznać tekst za artystyczny knot lub traktować implikowane przezeń znaczenia jako po Derridiańsku nierozstrzygalne. Oczywiście; obie możliwości nie wykluczają się wzajemnie i owa nierozstrzygalność dzieła może świadczyć po prostu o nieudolności pisarskiej autorki, która chroni się przed krytyką za parawanem quasi-filozoficznych wykładni.

6.

Za cechę pisarstwa postmodernistycznego uznaje się częstokroć właśnie nierozstrzygalność, ponieważ rozwija się ono jednocześnie na dwóch planach:

1. filozoficznym i literackim,

2. tetycznym (to dzięki niemu tekst może być czytany zgodnie z wymogami dyscypliny - filozofii lub literaturoznawstwa) i atetycznym (uwalniającym tekst od silnej teoretycznej konkluzywności i wpisujący go w niejednoznaczną przestrzeń dyskursów nieteoretycznych) - takie teksty w tym samym czasie o czymś mówią, o czymś orzekają i coś robią, działają,

3. asertorycznym i fikcjonalnym,

4. aletycznym (z grec. 'aletheia' - prawda) i tekstualnym.

Za każdym razem możliwe znaczenia rozpościerają się pomiędzy biegunami opozycji, nie zawierając się w żadnej z nich. A zatem nie chodzi o możliwość wyboru, lecz o sytuację, gdy trzeba zaakceptować obecność dwu jednakowo możliwych, a zarazem sprzecznych interpretacji (znaczeń, sensów), z których jedna odsyła do rzeczywistości zewnętrznej, a druga do innego tekstu.

Innymi słowy: nierozstrzygalna jest oscylacja między performatywem i konstatacją. Dzieło jest zdarzeniem, a zarazem performatywnie o tym zdarzeniu opowiada. Deridda mówi o błyskawicznej cyrkulacji między performatywem i konstatacją, która decyduje o nierozstrzygalności między tymi dwoma aktami mowy - „wytwarza zdarzenie poprzez sam gest opowiadania o nim". W ten sposób Derrida unika mimetologizmu, bo uchyla tezę o uprzedniości przedmiotu naśladowania wobec samego naśladowania. Ale jest sam proces naśladowania. Nierozstrzygalność ontologiczna znosi granicę wnętrze-zewnętrze, to założenie jest newralgicznym punktem koncepcji Derridy. Wiąże się antymimetologiczną koncepcją literatury oraz jej nierozstrzygalną oscylacją między konstatacją i performacją. 
Zawieszając elementarne rozróżnienia, na których opierała się nauka o literaturze, Derrida z góry kwestionuje posługiwanie się dotychczasowymi metodami badań literackich jako nieuprawnionymi:

By sprzeczne wartości (dobro/zło, prawdziwe/fałszywe, istota/pozór, wnętrze/zewnętrze itd.) mogły się sobie przeciwstawić, każdy z tych terminów musi być po prostu zewnętrzny wobec drugiego, to znaczy jako jedno z przeciwieństw (wnętrze/zewnętrze) musi być już przyjęte jako matryca wszelkiego możliwego przeciwieństwa. [...] Gdyby zaś dojść do przekonania, że coś takiego jak farmakon lub pismo - dalekie od podporządkowania się tym przeciwieństwom, otwiera ich możliwość, nie pozwalając się jednak zrozumieć za ich pomocą; gdyby dojść do przekonania, że tylko na podstawie czegoś takiego jak pismo - lub farmakon zapowiedzieć może swe nadejście nieznana różnica między wnętrzem i zewnętrzem; [...] to należałoby wówczas nagiąc do obcych ruchów to, czego nie można byłoby już nawet zwyczajnie nazwać logiką bądź dyskursem ${ }^{33}$.

W wywiadzie cytowanym przez Annę Burzyńską autor dekonstrukcji stwierdzil, że jedyna obowiązująca „Hierarchia dotyczy sil, nie zaś prawdy i fałszu"34. Chodzi mu zatem już tylko o konflikt różnych - silniejszych i słabszych - racji interpretacyjnych, nie zmierzający do arbitralnego rozstrzygnięcia. Pociąga to za sobą ryzyko dowolności, z którą walczy się w edukacji uniwersyteckiej. Lecz dla Derridy nie ma to żadnego znaczenia.

Podwojenie, polegające na byciu jednostkowym dziełem, a zarazem inscenizacją reguł jego powstawania, decyduje o przekroczeniu nienaruszalnej dotychczas granicy pomiędzy tym, co należy do świata dzieła, a co do rzeczywistości wobec niego zewnętrznej. To wahanie pomiędzy działaniem i oznajmianiem o istniejącym stanie, między językiem literatury a metajęzykiem komentarza, między tym, co jednorazowe i niepowtarzalne a tym, co konwencjonalne i zinstytucjonalizowane, między poszczególnymi komunikacyjnymi poziomami zarówno wewnątrz-, jak i zewnątrztekstowymi, między afirmacją i negacją - powoduje, że obszar literatury staje się polem gry. Spór o wartości i znaczenia okazuje się o tyle bezzasadny, że samo dzieło projektuje sprzeczne znaczenia i pozwala na współistnienie antynomii, a gra nie toczy się o wygraną, lecz jest kwestią przyjemności. Dodajmy jednak, że jest to walor niektórych tylko utworów i propozycje Derridy są o tyle ciekawe, że pozwalają wskazać zjawisko w tradycyjnym języku literaturoznawstwa do tej pory nierozpoznawalne.

Zdaniem niektórych badaczy dekonstrukcja Derridy nie jest niczym więcej niż kolejnym stylem odbioru dzieła literackiego, który można do-

${ }^{33}$ Derrida, Farmakon, w: Pismo filozofii, s. 53.

${ }^{34}$ A. Burzyńska, Dekonstrukcja i interpretacja, Kraków 2001, s. 472. 
pisać do systematyki Michała Głowińskiego ${ }^{35}$. Zbyt poważne są jednak jej konsekwencje dla całego gmachu nauki o literaturze, by poprzestać na takim sądzie. Propozycja Derridy nie mieści się w żadnej z dotychczasowych systematyk, ponieważ odwraca i burzy ich porządek myślenia. Czy jednak proponowana $w$ to miejsce metoda lepiej służy literaturze?

Sposób czytania proponowany przez Derridę zyskuje coraz więcej zwolenników. Wydaje się, że dziś czytelniczą przyjemność sprawia przede wszystkim nie to, co nieoczywiste, tajemnicze, co nie podsuwa prostych odpowiedzi, ale obiecuje odsłonięcie innego, lecz to, co z góry udzielenia takiej odpowiedzi odmawia, co wprowadza czytelników na ścieżkę wiodącą w kierunku innego, lecz co zarazem czyni ją aporetyczną, nie do przebycia. Inaczej mówiąc - to, co nierozstrzygalne.

Czy dzieje się tak dlatego, że ten sposób czytania mówi coś istotnego o nas samych, o świecie, w którym żyjemy i o roli samej literatury? $\mathrm{Z}$ pewnością tak. Choć - jako dość zawiły i niedookreślony - stwarza też doskonałą okazję do nadużyć i pozwala sprytnie kamuflować warsztatowe braki pod płaszczykiem dekonstrukcjonistycznej wolności.

Jeśli można zatem sformułować jakiś zarzut wobec tak skonstruowanej metody, to jest on na tyle poważny, że podważa same podstawy dekonstrukcji. Otóż przyjęcie tezy o nierozstrzygalności sensów niesionych przez tekst literacki unieważnia spór na temat wartości dzieła, projektowanego przezeń świata oraz światopoglądu, który - podpowiada nam zdrowy rozsądek -- niewątpliwie legł u jego podstaw.

Atrakcyjność czytania, polegająca na podniecającej nadziei dotarcia do istoty tekstu, przekształca się w rozczarowanie. Na każdym etapie analizy tekstu można przecież stwierdzić, że mamy oto do czynienia $z$ sensem nierozstrzygalnym, co równoznaczne jest $\mathrm{z}$ unieważnieniem każdej próby hermeneutycznego rozumienia utworu.

A w takim razie literatura przestaje być upoważniona do zadawania tzw. pytań istotnych, nie podsuwa możliwych rozwiązań, nie upoważnia do toczenia sporu o wartości, jest instytucją na pozór odideologizowaną i zależną wyłącznie od czytelnika, a to znaczy: jej funkcja kulturotwórcza zostaje zredukowana do zera.

Strategia nierozstrzygalności narusza przyjęte standardy komunikacji literackiej i burzy ustalenia tradycyjnej poetyki, manipulując częstokroć zależnością między mimesis i semiosis, których twarde rozróżnienie było do niedawna punktem wyjścia interpretacji utworu literackiego. W to niejsce wejść ma inna istotna funkcja, nazywana przez Derridę „odkrywaniem innego". W artykule Psyché. Odkrywanie innego pisze Derrida:

35 Por. M. Głowiński, Świadectwa i style odbioru, w: tegoż, Dzielo wobec adbiorcy. Szkice z komunikacji literackiej, Kraków 1998. 
Pozostaje do przemyślenia [...] nierozstrzygalność, która nie wiąże się już z porządkiem rachunku między dwoma biegunami opozycji, lecz z nieobrachowaniem czegoś całkiem innego: nadejściem lub wezwaniem innego. Powinno być ono nieprzewidywalne, przypadkowe, poza wszelkim rachunkiem ${ }^{35}$.

Dekonstrukcja zatem to nie rezygnacja z teorii na rzecz spontanicznej ekspresji, lecz stan nierozstrzygalności. To nieustanna negocjacja między tym, co jednostkowe i co ogólne; między tym, co jako idiosynkratyczne staje się nieczytelne dla innych a tym, co całkowicie wykładalne. Czytany tekst jest figurą inności: lektura umożliwia jego uobecnienie, a zarazem przeciwstawia mu tekst będący odpowiedzią na głos innego. Czy jednak ów głos innego nie stanie się kolejną złudną projekcją wyobrażeń czytelnika na jego temat? I jak uniknąć ponownego wpadnięcia w pułapkę erudycyjnego gadulstwa, które tradycyjną poetykę przekształciło, zdaniem Derridy, w „analfabetyczne scjentyzmy, płaskie i obskuranckie" 36 ?

Gdy dzieło literackie traktować będziemy jako maszynę do produkcji znaczeń, zaś interpretację - jako intelektualną grę, której wynikiem może być co najwyżej remis, to nauka o literaturze musi popaść w impas. O co zresztą tak naprawdę zdaje się chodzić Derridzie uparcie kwestionującemu naukowość podstaw badań literackich. Gdyby jednak naprawdę udało mu się ten cel osiągnąć, kto właściwie miałby czytać jego artykuły, których hermetyczny język wymaga sporej dozy wytrwałości i szacunku dla słowa pisanego, jakimi obdarzeni są literaturoznawcy?

O ile bowiem Derrida dowartościowuje każdy przejaw inwencji czytelnika, uznając ją za równoprawną odpowiedź Innego na inność tekstu, o tyle własnych czytelników - których przeważająca większość to badacze literatury - traktuje bezwzględnie, odmawiając im prawa do obrony własnego stanowiska, z którego dokonują krytycznego rozbioru jego dzieł, z góry posądzając ich o zamiary totalizujące.

35 J. Derrida Psyché. Odkrywanie innego.

36 J. Derrida, Signeponge/Signsponge, New York 1984, cyt. za: K. Kłosiński, Niewyrażalność a niereferencjalność. Poetyka $w$ świetle dekonstrukcji, w: Literatura wobec niewyrażalnego, red. W. Bolecki i E. Kuźma [brak miejsca i roku wydanial 